\title{
Politeness Strategies Used by the Member of Student Youth Community (SYC) Widya Gama Mahakam University
}

\author{
Febiyani $^{1)}$, Rinda Fitriana ${ }^{2)}$, Arbain ${ }^{3)}$ \\ ${ }^{1)}$ Program Studi Pendidikan Bahasa Inggris, Fakultas Keguruan dan Ilmu Pendidikan, \\ Universitas Widya Gama Mahakam Samarinda, Indonesia \\ Jl. KH. Wahid Hasyim No. 28 RT.007 Kota Samarinda, Provinsi Kalimantan Timur \\ ${ }^{2}$ Program Studi Pendidikan Bahasa Inggris, Fakultas Keguruan dan Ilmu Pendidikan, \\ Universitas Widya Gama Mahakam Samarinda, Indonesia \\ Jl. KH. Wahid Hasyim No. 28 RT.007 Kota Samarinda, Provinsi Kalimantan Timur \\ 3) Program Studi Pendidikan Bahasa Inggris, Fakultas Keguruan dan Ilmu Pendidikan, \\ Universitas Widya Gama Mahakam Samarinda, Indonesia \\ Jl. KH. Wahid Hasyim No. 28 RT.007 Kota Samarinda, Provinsi Kalimantan Timur \\ *Email Penulis Korespondensi: fyani26@gmail.com, rinda@uwgm.ac.id, baintigers@gmail.com,
}

\begin{abstract}
Politeness strategy is a strategy that used by the people in order to safe and satisfy the hearers' face. This strategy mainly used in everyday communication and interaction. This research used qualitative resarch and aimed to find what are politeness strategies used by the member of Student Youth Community (SYC). This research conducted in Widya Gama University with 15 members of SYC who involved as the research subject. The result of this research showed that there are four strategies used by the Members of SYC. They are bald on record, positive politeness strategy, negative politeness strategy, and off record strategy. From 277 utterances, 116 utterances of them recognized as bald on record (42\%), 110 utterances as positive politeness $(40 \%), 18$ utterances as negative politeness $(6 \%)$, and 33 utterances as off record (12\%). Therefore, it can be concluded that bald on record as the dominated strategy that used by the members of SYC. It means that, during the discussion and interaction, the members of SYC tend to use direct srategy.
\end{abstract}

Keywords: politeness, politeness strategy, pragmatics 


\section{INTRODUCTION}

Pragmatics is a branch of linguistics which focuses on the meaning of the sentence. In term of communication, pragmatics deals with the meaning of utterance that depends on the speaker and the context or situation. Basically, Yule (1996) scrutinizes definition of pragmatics into four aspects. First, He defines pragmatics as the study of speaker meaning. He emphasized on meaning delivering by the speaker and what listener interpret. In this context, pragmatics analyzing focuses with the study of meaning delivered by the speaker and defined by the listener. It concerns with the analysis of the meaning of people's utterance rather than the meaning of word or phrase literally.

In the second aspect, Yule (1996) relates pragmatic to studying contextual meaning. He described that pragmatic studying meaning depending on the context. Meaning that people need to consider about to whom they are talking to, the time and the place and the circumstances where the conversation occurs. In this type, the speaker needs to know in what context or situation he/she talking in. Besides, the speaker also has to consider their utterance based on who is the hearer talking with.

In the third aspect, Yule (1996) stated pragmatic as the invisible meaning. He explained that things which are unspoken to the speaker also considered as part of what the speaker delivered. It implies that pragmatic also concern with meaning delivered by the speaker even it is unspoken. As the last aspect, Yule (1996) explained pragmatic as a study of the expression of relative distance. He emphasized that the pragmatic also depends on the relation between the speaker and the listener. He indicated that in conversation, the speaker will consider how much he/she needs to say according to how close the listener is.

In addition, Griffiths (2006) explained that pragmatic concerning in the utilize of speech in a situation, concerning the way to manage to express more than what is exactly the semantic of sentence encoded.Horn and Ward (2006) also stated that pragmatics is the research of situation-suspended feature of meaning which is methodically parted away from in the interpretation of substance or rational type.Thomas (2013) added that Pragmatics is an utterance produced by the speaker and hearer which is not inherent to the words alone. Meaning that in speaker's utterance, there is a meaning which comes from a dynamic process. This concept engaging the compromise of meaning between speaker and hearer, the background of utterance (substantial, societal, and language) and the potential meaning of the utterance. 
Hence, it can be concluded that pragmatic is a study which concerns about the meaning of language or utterance that considered by some factors such as the context, someone that the speaker talking with, and the relation between the speaker and the listener. Therefore, the understanding of the pragmatic is about the meaning that related to the utterance and the context in communication.

Politeness deals with human's act and behavior in treating someone. In society, politeness basically concerns about the etiquette and attitude of people when communicate or interact with each other. Based on Brown (2015) explained that there are three kinds of politeness. First, politeness as social rules, in this definition, politeness defines as a concept of rules in social behavior, rules for speak and manner stemming normally from a high level of person or community. Secondly, politeness as obedience to politeness maxims. It is an option method obtains the place that the linguistic forms of politeness are not about the subjective rule but are made by universal rule. Thirdly, politeness as face management, this definition puts 'face work' at the center of politeness.

Furthermore, according to Spencer-Oatey (2008), In everyday life, politeness is often interpreted as the use of proper and respectful language relatively, for instance, proper expression such as 'Sir' or 'Madam', request term like 'would you be so kind as to... .,' and proper term of gratitude and apology. Furthermore, politeness is a social thought, and speakers are considered to be polite or impolite relying on what they say in what context. In this case, politeness is an issue about suitability.

In conclusion, politeness is the use of an appropriate word in appropriate context. Politeness concern with language use in the society which means that in communication, people should consider about social rules in every context or situation. Thus, the communication and interaction must follow the rules which related to the language norm in society.

There are some theories about politeness strategies proposed by the experts. First, types of politeness strategies by Lakoff (1973). Lakoff (1973) in Ahmed (2016) claimed that politeness phenomena happened when the language users preferred a set of strategies in their utterance. She also added that politeness as a method of interpersonal connections intended to assist communication by reducing the possible clash and argument inherent in all individual deviation. According to her, there are three rules of politeness strategies; 1) don't impose, 2) give option, 3) make a feel good. 
In addition, there are also a theory from Leech (2014) who stated thatthere are 10 types of politeness strategies namely; give a high value to O's wants (generosity maxim), give a low value to S's wants (tact maxim), give a high value to O's qualities (approbation maxim), give a low value to S's qualities (modesty maxim), give a high value to $\mathrm{S}$ 's obligation to $\mathrm{O}$ (obligation of $\mathrm{S}$ to $\mathrm{O}$ maxim), give a high value to O's opinions (agreement maxim), give a low value to S's opinions (opinion-reticence maxim), give a high value on O's feelings (sympathy maxim), and give a low value to S's feelings (feeling-reticence maxim)

Meanwhile, according to Brown and Levinson (1987) there are four types of politeness strategies. First, bald on record strategy; it is a direct strategy. The speaker uses this strategy to express the utterance clearly and briefly without any redress. This strategy used when the speaker does nothing to minimize the listener's face. This type commonly using by people who know each other very well such as a friend. Second, positive politeness; it is adjusted to gratify listener's positive face. It means that speaker indicates his recognition, acceptance, readability, and solidarity with the hearer. This strategy using some mechanisms, there are claim common ground with the listener, deliver that speaker and listener are cooperator and satisfy listener's want. Third, negative poliiteness; it is a type of politeness which concerns on how to satisfy listener's negative face. It deals with respect behavior. By doing this strategy, the speaker has a purpose to stress listener's authority. This strategy's results are helpful for keeping social distance. The last is off record strategy; it is an utterance that has a purpose. When speaker using off record strategy, he/she not only give a direct information, but he/she also has their own purpose. In simply, this strategy using indirect language in the communication between speaker and listener.

In this research, the researcher decided to use politeness strategies theory by Brown and Levinson (1987). It is because the types of politeness strategies that provided by Brown and Levinson (1987) are more specific than other theories. Besides, Brown and Levinson's' theories have covered all of the politeness strategies that commonly used in speakers' utterance.

\section{METHODOLOGY}

This study deals with describing politeness strategies used by the members of SYC. This research used the qualitative research method with case study design. Qualitative research was chosen because this research aims at obtaining an information about the use of politeness strategies usedby the members of SYC Community. Creswell (2014) stated that qualitative research was chosen by the researcher when the researcher tries to find and set up the sense 
of occurrence from the participants' view.It indicates to recognize a culture-sharing group and learning how it expands shared model of action over the occasion. One of important thing of collecting data in this method is to investigate the behavior of the participants throughout their activity.The data were collected by using observation with video-recorded from three different meetings. Observation guide were used as the instrument of the research.

The research subject in this research were the participants of SYC Widya Gama Mahakam University. SYC was chosen by the researcher because this community is one of the English club community in Widya Gama Mahakam University Samarinda. In this research, the researcher observed three meetings of SYC in three weeks because the researcher wanted to know the use of politeness strategy among the members during three meeting in a row.

In order to collect the data, the researcher made an observation guide as the instrument. Then the researcher came to the class when the meeting started. During observation, the researcher recorded the conversation and interaction among the members during the meeting by using a recorder. Then, In order to make it easy, the researcher wrote the script from the video record for collecting data and deciding the sections of the utterances which have the forms of politeness strategies.

The pragmatic analysis used in this research was based on Brown and Levinson's politeness strategies. The data were analyzed based on the model analysis introduced by Miles et. al (2014), which involves data condensation, data display and conclusion. In order to simplify the data, the reseearcher reduced the data using data coding.

\section{FINDINGS AND DISCUSSION}

This section describes the result of the analysis of the utterances by the member of SYC. From the subjects of the research, the researcher found there are 277 sutterances during three meetings that consists of 116 utterances of bald on record, 110 utterances of positive politeness, 18 utterances of negative politeness and 33 utterances of off record strategy. Based on the analysis, the researcher found that all of the members of SYC used all types of politeness strategies from Brown and Levinson (1987) theory. In general, the use of politeness strategies in SYC community is represented in the chart below: 
Figure 1 The Use of Politeness Strategies in SYC

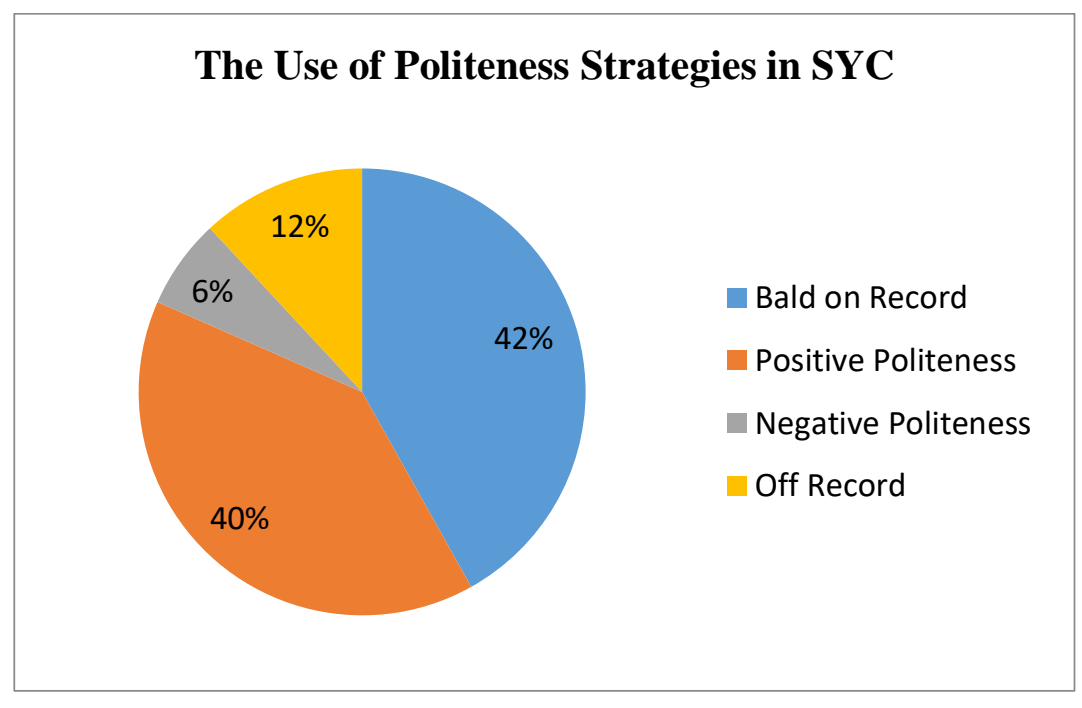

(1) Bald on record

Bald on record is basically depicted as a type of utterance expressed directly by the speaker. Meaning that, the speaker tells the hearer about what he/she wants explicitly and directly. In this strategy, the researcher found that there are 116 utterances of bald on record strategy. The use of bald on record strategy by the member of SYC Community consists ofeight types of strategy. They are 25 utterances of maximum efficiency (22\%),four utterances metaphorical urgency for high valuation of hearer's friendship (3\%)40 utterancse of taskoriented/paradigmatic form of instruction (34\%), six utterances of sympathetic advice or warnings (5\%), 12 utterances of granting permission (10\%), six utterances of welcoming $(5 \%)$, an utterance of farewell (1\%), 22 utterances of offer (19\%). The distribution can be seen in the following figure.

\section{Excerpt 31 (Task Oriented)}

P11: Just speak. right?

P7 : Ya. Just speak

P2 : Andi first!

M1.L194-L196.P2.BOR.TOR

The conversation above showed that speaker employs bald on record strategy namely task oriented. The word "Andi first!" in the utterance above showed the use of task oriented because in his utterance, the speaker (P2) gave a task to the hearer to be the first to deliver the answer. 


\section{Figure 2 The Use of Bald on Record}

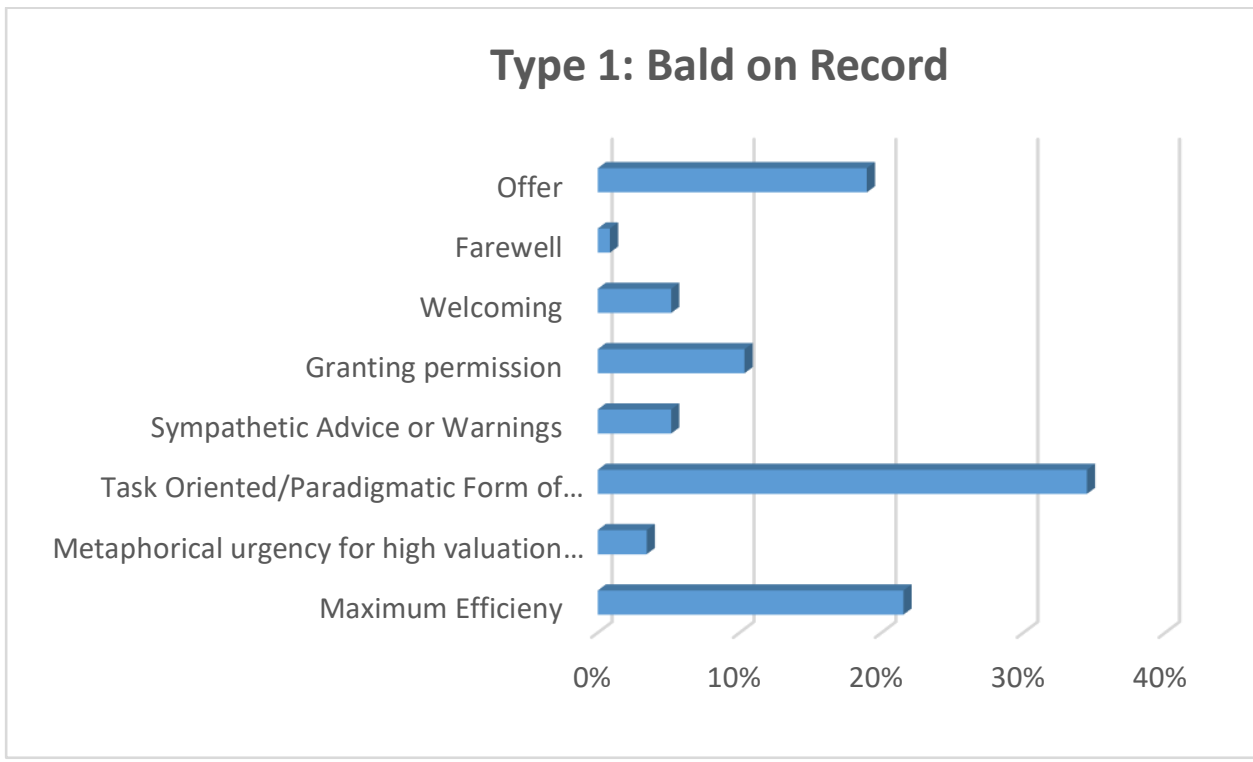

(2) Positive Politeness Strategy

Positive politeness strategy is a strategy which used by the speaker to satisfy hearer's positive face. This strategy aims to fulfill the interest, needs, wants, and goods of the hearer. In this strategy, the researcher found that there are 110 utterances of positive politeness strategy. The use of positive politeness strategy by the member of SYC Community consists often types of strategy. They are four utterances of maximum notice attend to hearers (4\%), four utterances of exaggerate (4\%), 41 utterances f use in group identity maker (37\%), 20 utterances of seek agreement (18\%), five utterances of avoid disagreement (5\%), seven utterances of joke (6\%), four utterances of offerand promise (4\%), four utterances of include both $\mathrm{S}$ and $\mathrm{H}$ in the activity (4\%), 17 utterances of give or ask reason (15\%),four utterances of give gift to hearer $(4 \%)$. The distribution can be seen in the following figure.

\section{Excerpt 117 (Notice attend to hearer)}

P2 : Make it slowly.

P3 : Very slowly.

P2 : And make e.. speak aloud.

P12: Speak loudly. Ok, so again more slowly and loud.

M1.L288-L291.P12.PP.NATH

The conversation above showed that the speaker employed positive politeness strategy namely notice attend to hearer. The word "Ok, so again more slowly and loud" showed the use of notice attend to hearer. The utterance showed that the speaker (P12) pay attention to 
the hearer's need. The speaker knew that the hearer was confused because she speaks too fast. As the way of fulfiling the hearer's need, she repeated her speech slowly.

Figure 3 The Use of Positive Politeness Strategy

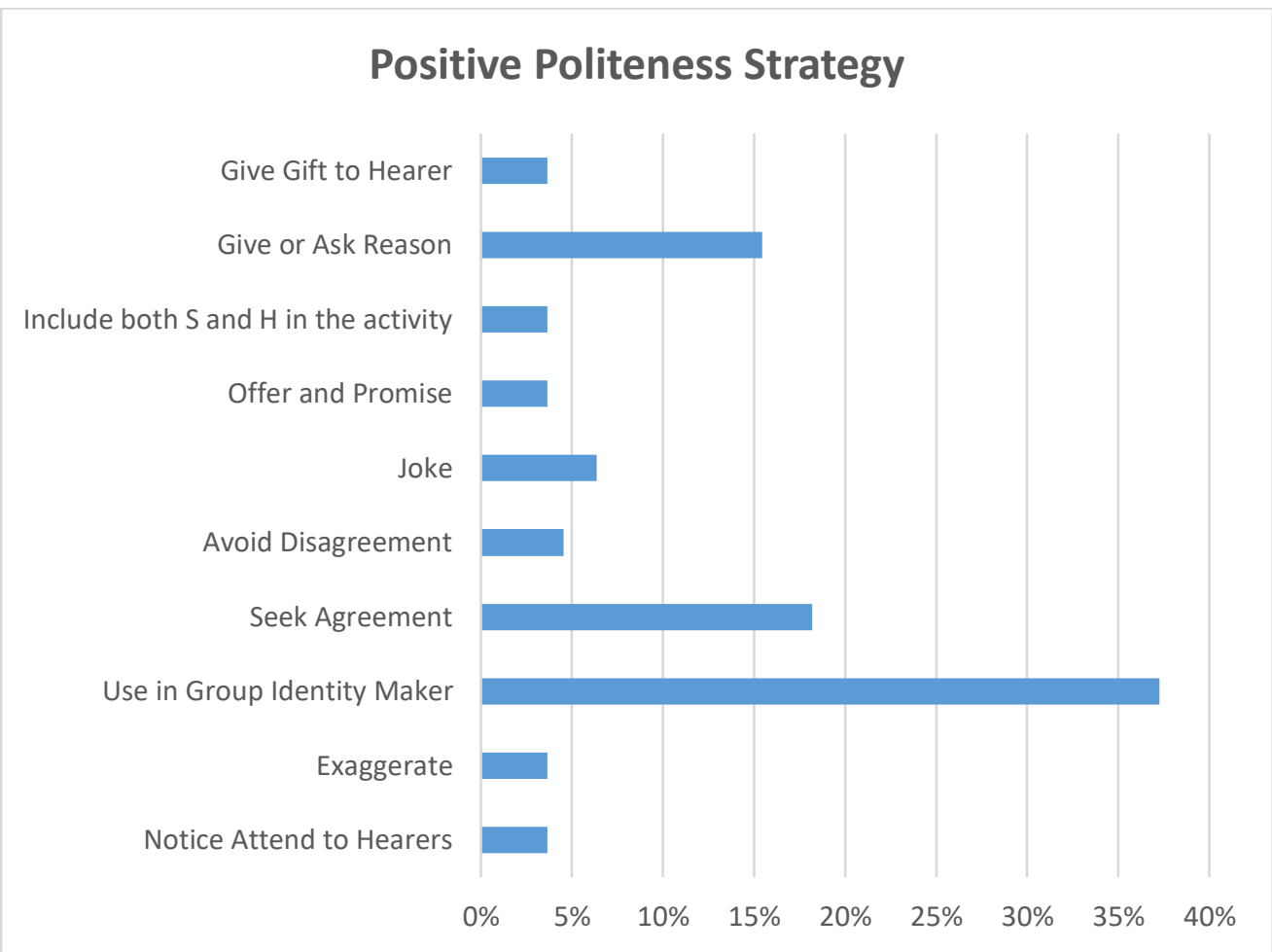

(3) Negative Politeness Strategy

Negative politeness strategy deals with respect behavior. The main purpose of this strategy is to satisfy the hearer's negative face and to keep social distance. In this strategy, the researcher found that there are 18 utterances of negative politeness strategy. The use of negative politeness strategy by the member of SYC Community consists ofthree types of strategy. They are six utterances of question hedge (33\%), 10 utterances of apologize (56\%), and two utterances of impersonalize speaker and hearer (11\%). The distribution can be seen in the following figure.

\section{Excerpt 227 (Question hedge)}

P2: It's just e... just example.

Ps: (laughing)

P1: So, this is the real one ya. I think it could be start from you.

P2: Ya.

M2.L38-L41.P1.NP.QSHD

The conversation above showed that speaker employed negative politeness strategy namely question hedge.The word "I think it could be start from you"showed the use of question, 
hedge. In this utterance, the speaker (P1) asked the hearer to start the game. By using this strategy, the speaker (P1) wanted to soften command and turned it into polite suggestion.

\section{Figure 4 The Use of Negative Politeness}

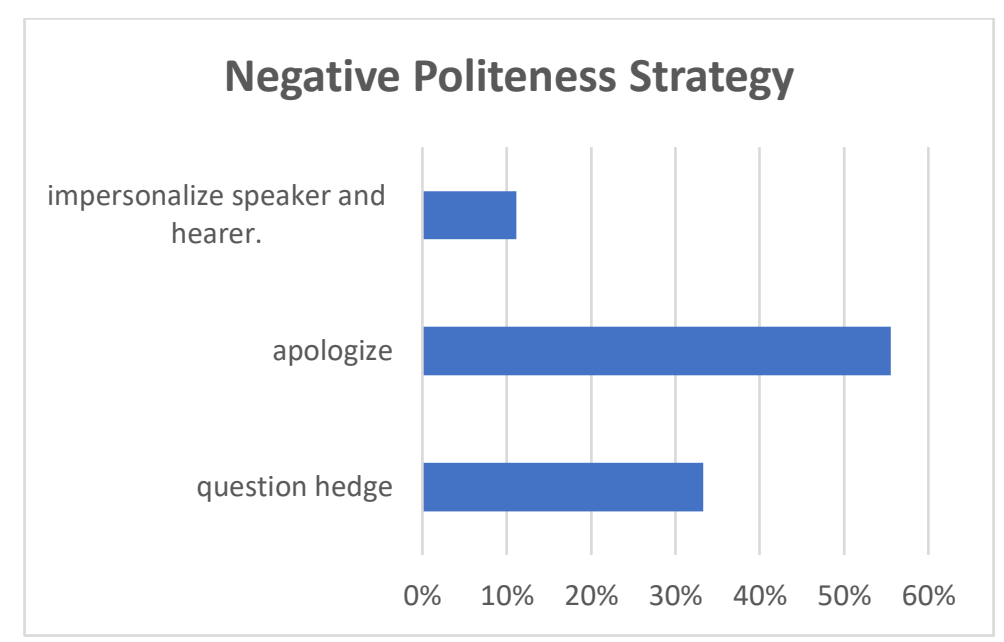

(4) Off Record Strategy

Off record trategy is an indirect strategy. In doing this strategy, the speaker uses indirect utterance because he wants the hearer to interpret the meaning of his utterances. In this strategy, the researcher found that there are 33 utterances of off record strategy. The use of off record strategy by the member of SYC Community consists offive types of strategy. They are five utterances of give hints (15\%), 12 utterances of use contradiction (36\%), two utterances of use rhetorical question (6\%), three utterances of over generalize (9\%), and 11 utterances of be incomplete use elipsis (33\%). The distribution can be seen in the following figure.

\section{Excerpt 245 (Give hints)}

P3: You lie you lie

P8: You twenty eight

Ps : Sstttt...

M1.L94-L96.Ps.OR.GVHN

The conversation above showed that speaker employed off record strategy namely give hints. The clue "Sstttt..." showed the use of give hints. The utterance above showed that the participants was disturbed by the speaker $(\mathrm{P} 3, \mathrm{P} 8)$ because they were noisy. The participants said that utterance to give a clue to the speakers and hoped the speakers know what they mean. In this case, the participants hoped the hearers to be quiet. 


\section{Figure 5 The Use of Off Record Strategy}

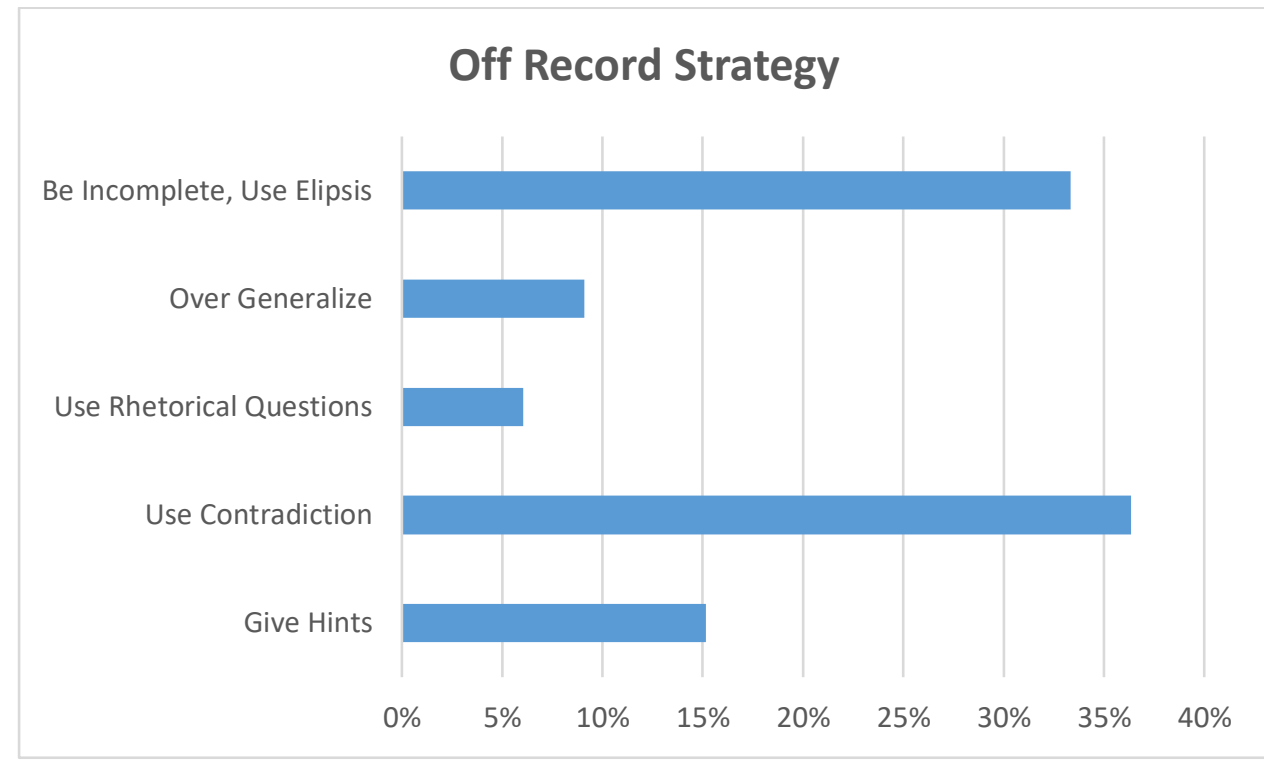

This study aims to answer a research question.

\section{Research question: what are politeness strategy used by the member of SYC Community?}

To answer this question, the researcher had conducted observation in three meetings. As the result, from the total number of 277 utterances, the researcher found 116 were used bald on record strategy, 110 used positive politeness strategy, 18 used negative politeness strategy, and 33 used Off-record strategy. Bald-on record strategy is the most widely used by the subject, followed by positive politeness strategy in the second position. Off record and Negative politeness strategy in the third and fourth position.

In this research, bald on record strategy is the most used strategy. It indicates that the member of SYC Comunity is highly used directness in their utterance. It is similar to Brown and Levinson theory (1987) who stated that bald on record is a direct strategy which used by the speaker in order to express the utterance clearly and briefly without any redress.

\section{CONCLUSION}

This study aimed to investigate the politeness strategy used by the member of English Club in Widya Gama University namely SYC Community. The research focused on the types of politeness strategy that used by the member of SYC Community while they conducted their meeting. To gain the data, the researcher did the observation for three meetings in a row. 
Based on the research findings and discussion in the previous chapter, the researcher concludes that all politeness strategies can be found in the member's utterances. The researcher found out that there are 277 data ofutterances. The data contain 116 data of bald on record strategy, 110 data of positive politenessstrategy, 18 data of negative politeness strategy, and 33 data of off record strategy. Itindicates that bald on record strategy noted as thedominant strategy.Meanwhile,negative politeness strategy is the less dominant strategy. 


\section{BIBLIOGRAPHY}

[1] A. Ahmed, Approaches In Linguistic Politeness: A Critical Evaluation, vol. 3. 2016.

[2] P. Brown and S. C. Levinson, Politeness : some universals in language usage. Cambridge [Cambridgeshire]; New York: Cambridge University Press, 1987.

[3] P. Brown, "Politeness and language," in The International Encyclopedia of the Social and Behavioural Sciences (IESBS),(2nd ed.), Elsevier, 2015, pp. 326-330.

[4] U. Flick, “An Introduction To Qualitative Fourth Edition,” SAGE Publ., p. 506, 20010.

[5] Spencer-Oatey, Helen, Culturally speaking: culture, communication and politeness theory, second edition. London/new york, 2008.

[6] L. Horn and G. Ward, The handbook of pragmatics, vol. 26. John Wiley \& Sons, 2008.

[7] K. Kurniyatin and B. S. Rochmat, "An Analysis of Politeness Strategies used by Teacher and Students in English Class at MTs NU Assalam Kudus.” IAIN Surakarta, 2017.

[8] G. Leech, “The Pragmatics of Politeness,” Pragmat. Politeness, pp. 1-368, 2014.

[9] S. Manik and J. Hutagaol, “An Analysis on Teachers' Politeness Strategy and Student's Compliance in Teaching Learning Process at SD Negeri 024184 Binjai Timur Binjai-North Sumatra-Indonesia,” English Lang. Teach., vol. 8, no. 8, p. 152, 2015.

[10] J. Miles, M. B., Huberman, A. M., \& Saldana, Qualitative Data Analysis. London: SAGE, 2014.

[11] S. M. R. Adel, M. Davoudi, and A. Ramezanzadeh, "A Qualitative Study of Politeness Strategies Used by Iranian EFL Learners in a Class Blog.," Iran. J. Lang. Teach. Res., vol. 4, no. 1, pp. 47-62, 2016.

[12] P. Griffiths and C. Cummins, An Introduction to English Semantics and Pragmatics. Edinburgh University Press, 2016.

[13] S. Umayah, I. N. A. J. Putra, and G. A. P. Suprianti, "POLITENESS STRATEGIES IN TEACHER-STUDENTS CLASSROOM INTERACTION AT THE ELEVENTH GRADE STUDENTS OF SMK PGRI 1 SINGARAJA,” J. Pendidik. Bhs. Ingg. undiksha, vol. 4, no. 2, 2018.

[14] M. Ryabova, "Politeness Strategy in Everyday Communication," Procedia-Social Behav. Sci., vol. 206, pp. 90-95, 2015.

[15] A. Sülü, “Teacher's politeness in EFL class,” Int. Online J. Educ. Teaching/ISSN 
2148-225X, vol. 2, no. 4, pp. 216-221, 2015.

[16] J. A. Thomas, Meaning in interaction: An introduction to pragmatics. Routledge, 2014.

[17] R. Yule, G., \& Stalnaker, Pragmatic Synthese. New York: Oxford University Press, 1996.

[18] J. W. Creswell, Research Design. Cambridge [Cambridgeshire]; New York: SAGE, 2014. 